\title{
You know what we need?
}

\begin{abstract}
I've listened to many of you moan about the current flat NIH budgets, lack of funding, and the frustration of being a scientist in the current depressed economy. Instead of complaining to only ourselves in the scientific community, we need to make ourselves heard by politicians and the public at large. We need a pundit.
\end{abstract}

What exactly is a pundit? According to Wikipedia, a pundit is defined as someone who offers to the mass media his or her opinion or commentary on a particular subject area on which they are knowledgeable. Most pundits in the US are brought to us via radio and television news outlets like CNN and Fox News, and their realm is largely political: think Bill O'Reilly, Rush Limbaugh, and Rachel Maddow. These TV personalities spend most of their airtime trying to one-up each other by bringing strong views, biased opinions, and - sometimes - expertise to the table. The inevitable fracas stirred up with their invited guests can make for riveting television. For this reason, viewers pay attention and often form their opinions based on the talking points fed to them by their favorite pundit.

But why would I recommend that the scientific community find itself a televised talking head in the mold of a conservative blowhard like Glenn Beck as a solution to a lack of funding? Over the last few years, I have heard no shortage of complaining about decreased funding; the most popular excuse I hear from those of you tardy with your reviews is that you're applying for yet another grant to keep your lab afloat. But to whom are we complaining? Ourselves! The auto industry flailed, the banking industry failed, and due to their significant lobbying efforts and visibility in the media, the US government bailed out both industries. But what about the scientific enterprise? Has there been much coverage of the lack of scientific funds in the popular media?

Marketing ourselves and our achievements should be the number one priority. However, as a group, I think scientists are a bashful crowd, not usually the sort to stake a flag and proclaim the cure of a scourge or an amazing advance. Scientists in general are often too conservative when it comes to spin, especially when it comes to talking with reporters from the popular press. (At this point, though I want to note for the record that I am not endorsing exaggerated conclusions in your actual scientific articles - in fact, the press releases that my fellow JCI editors and I write are often quite circumspect in their extrapolation to therapy, given that we largely publish work done in animal models.) Why are we purposefully underselling ourselves? Don't most therapeutic advances start with an observation in a cell or in an animal? Can't we be more proud about the work we've done and put up our peacock feathers sometimes? We can't claim we've cured cancer with a therapy that is only proven in a mouse, but my point is that we as scientists need to be less reserved and timid. We need to get the public to support science and the advances it brings, and the best way to do that is to increase our visibility.

So who should this savior of science be? I'm taking nominations and will be happy to help with the ascent of a pundit to a global stage if I can. Whoever he or she is to be is going to have to be charismatic, stylish, and witty. It has got to be someone already trained as a scientist, with an appropriate CV behind him or her to exude the sort of gravitas the networks will need. Popular pundits score with networks and producers when they have wide enough appeal and allure to draw a large audience while still being focused and informed enough to present their points well. Being a pundit need not be a full-time career, but getting the sort of widespread exposure to be effective may take an enormous amount of time - and that may not be compatible with running a successful lab.

The toughest part of the job will be developing the ability to reduce complicated scientific concepts to talking points. In October 2008, the former politician and current pundit Sarah Palin proclaimed that "dollars go to projects that have little or nothing to do with the pub- lic good - things like fruit fly research in Paris, France. I kid you not." Palin is an easy mark for most scientists to rebut, but it is exactly this sort of remark that our scientific pundit will have to address. He or she will have to be able to explain in 20 seconds or less how Drosophila melanogaster is the basis of human genetic research and that Thomas Hunt Morgan won the Nobel Prize in 1933 for demonstrating with fruit flies how inherited traits are passed to the offspring via chromosomes - all the while making it a relatable, interesting story that even Joe the Plumber would appreciate.

Remember Carl Sagan? He was an astronomer, physicist, and science communicator who had a 13-episode television show on PBS in 1980 that was riveting to my impressionable young mind. He made the origin of life and the lives of stars captivating. Today we have more science programs, but none that have made the presenter a star - no one scientific person is regularly invited to weigh in on matters of scientific policy. While I can name several experts I've seen on various programs, the only ubiquitous scientist regularly seen by the American public is CNN's neurosurgeon medical correspondent Sanjay Gupta. However accomplished as he may be, I have not heard Gupta speak broadly about basic science and the plight of the scientist in today's global economy.

While it is probable that various NIH institute directors and the NIH director himself spend a significant portion of their time asking congress and the president for more funding, they'll only get it if there is vast public support. Actually, given that public opinion of the bailouts for the automobile and banking industries was at best mixed, what we need may not be support but simply wider recognition of the problem. Isn't the scientific industry too big to fail as well? Shouldn't we be just as important to support? We just have to find the right person to deliver our message: someone to stand up and speak out. Let's call CNN. I'll bring the soapbox.

\section{Ushma S. Neill, Executive Editor}

